\title{
NATURAL RETREATS AND HUMAN WELL-BEING: READING THE SONG OF SONGS THROUGH THE LENS OF ATTENTION RESTORATION THEORY
}

\author{
Hendrik Viviers \\ Department of Religion Studies \\ University of Johannesburg
}

\begin{abstract}
Working within the field of environmental psychology, Rachel and Stephen Kaplan developed their Attention Restoration Theory (ART) to address the problem of directed attention fatigue. 'Involuntary' attention can put the voluntary or directed attention mechanism at rest, to enable it to function effectively again. This happens markedly (but not solely) within natural settings that are both wild (e.g. reserves) and domesticated (e.g. gardens). Notions such as 'being away,' 'soft' fascination,' 'extent' and 'compatibility' aptly describe the human nature relationship, and function as descriptive properties that natural settings require to enhance the restorative experience. ART has lately become extended to many fields to explain more than just focus, but overall human well-being and the facilitating role nature plays in this 'healing' process. Shining the light of these insights onto the Song of Songs, it was determined that this ancient book had an (intuitive) appreciation for nature's healing/restorative powers. The focus was especially on the natural retreats of which the two young lovers often avail themselves (e.g. 1:15-17; 2:8 ff.; $6: 11-12 ; 7: 11-13 ; 8: 5 ; 8: 13-14)$ to escape their inhibiting society, and on how these retreats (unknowingly) comply with the mentioned restorative requirements.
\end{abstract}

Key Words: Attention Restoration Theory; Directed Attention Fatigue; Involuntary Attention; Fascination; Compatibility; Being Away; Extent; Nature; Natural Retreats; Song of Songs

\section{Introduction}

There is a global trend towards greater urbanisation but people do not seem to have outgrown their rural/nature roots. Most people would admit to be touched by the beauty of nature when exposed to it in whatever way, which is understandable since we are part and parcel of nature, fully integrated into the web of life as we know it. This intimate connection to nature is aptly explained by the Biophilia Hypothesis, which its founder EO Wilson describes as "...the innately emotional affiliation of human beings to other living organisms" (1993:31). People universally have an inborn, spontaneous attraction to their life-infused natural surrounds. The urge of people to escape their daily toil and retreat regularly to some inspiring natural environment (even a walk in the suburban park) to become replenished, is conspicuous. What in nature specifically and in ourselves spawns this beneficial effect, confirming the spontaneous resonance between us and the natural environment? A convincing (scientific) answer explaining the change from fatigue to 
replenishment with nature as 'partner,' comes from Attention Restoration Theory (hereafter ART). This theory offers a psychological perspective explaining some of the mind's mechanisms to become restored and ensure our overall well-being (see discussion below). ART builds on the Biophilia Hypothesis (Frumkin 2001:236) and becomes a concretisation thereof. ${ }^{2}$ Where Biophilia represents a broad and general point of departure to emphasise the human bond with nature, $\mathrm{ART}^{3}$ endeavours to explain the specifics of our mental abilities, what happens in the human mind when exposed to nature, enhancing our well-being. At the outset it must be emphasised that ART, as its name indicates, is more than just regaining our focus, which prompted its initial conceptualisation. The examples further on will show that its application nowadays in diverse fields includes our overall well-being (therefore also the specific formulation of this article's title), always with the spontaneous embracing of nature. With the help of nature our minds 'heal' us physically and emotionally to become well-adapted, happy and coping persons. Nature, however, cannot be just any piece of nature anywhere but needs to meet the properties of 'being away' (to be exposed to new cognitive content), compatibility (fit the purpose of being there), fascination (wonderment) and extent (rich in scope and content).

The realisation to become restored through nature is not something discovered only recently. Even the ancients experienced the replenishing effect of nature exposure, long before science supplied its theoretical and empirical foundations. Utilising the insights of ART, Thielen and Diller (s.a.) delved into history to show how gardens of old were crucial for learning and contemplation, and unknowingly met the requirements of ART. What did great thinkers such as the Greek and Roman philosophers Plato, Epicurus, Cicero and Pliny the Younger, $10-12^{\text {th }}$ century Confucian thinkers at the Yuela Academy and more modern names from the English world like Desiderius Erasmus, Sir Isaac Newton and Arnold Toynbee have in common? Thielen and Diller show that their academies, schools, monasteries, libraries and laboratories were all adjacent to inspiring gardens: “...one of the preferred ways to learn, study, and find intellectual inspiration was through wandering in a villa or academy garden" (s.a.:8).

Might the ancient book of Song of Songs also reflect a similar appreciation for the replenishing value of nature, unknowingly confirming the insights of ART? The Song's principal metaphor has been aptly described by Landy (1983:31) as a 'rural retreat,' but from what did the two young lovers get away to become replenished? It is so that the Song is overwhelmingly, sometimes even naively concerned with the phenomenon of love, as if this is the only thing in life that matters. This can obviously be expected as we meet the two main characters 'besotted' with love (Exum 2005:6). All in the Song is, however, not idyllic. Even though the references in the Song to wine, milk, honey, oil and pomegranates might evoke paradise-like associations, these foods represent the standard agricultural products of Israel (Num 13:23), implying daily and cumbersome toil (Fontaine 2001:131).

1 The timely emphasis on nature as a non-human 'partner', as a 'subject' with 'agency' in her own right is aptly demonstrated by Norman Habel in his recent Earth Bible commentary on Genesis 1-11. He describes Adamah or Earth as "... a pivotal subject in the plot of the myth ... God's partner in the creation of all life on Earth" $(2011: 48,51)$. This is also the view of nature adopted in this article, even though I don't always explicitly indicate her as such.

2 The psychologist Stephen R Kellert (1993:42) represents another example of elaborating on the Biophilia Hypothesis's emphasis on nature for its cognitive, emotional, aesthetic and spiritual value. He emphasises several qualities of nature (e.g. utilitarian, naturalistic, ecologistic-scientific, aesthetic, symbolic, humanistic, moralistic, dominionistic, negativistic) that are shared globally.

3 Other informative psychological perspectives, e.g. developmental (Melson 2013) and emotional (Myers et al. 2004; Keltner \& Haidt 2003) emphasise the human: nature bond in their own unique ways. 
The cultural patriarchal code is also unmistakably present in the Song, inhibiting the two lovers' movements and actions, especially those controlling the young woman. It is her brothers that confine her to the vineyards as a keeper (Song 1:5-6), almost matching their efforts to also keep her 'indoors', away from young male suitors (Song 8:8-10). A respectable woman needs to be indoors at night as she discovers when seeking her lover but gets beaten by the city guards (Song 5:2-8). She wishes for her lover to be a 'brother', to be able to kiss him in public and not be scorned (Song 8:1). Fontaine emphasises their need for privacy from the glaring, censoring eyes of their community. She speaks insightfully of their longing "to get away from it all" (2001:130) and herewith uses almost the exact same words of the first property of ART, namely 'being away', indicative of the ancient Song's intuitive grasp of some of the insights of this theory. These few comments indicate a fruitful breeding ground for boredom, tension, anxiety and stress and make the escape to nature to become replenished meaningful. ${ }^{4}$ Even though the Song reflects a typical preindustrial (agricultural) society it does not differ in essence from a modern city where these same anxieties occur in work and living situations, urging urbanites to escape to nature (even a local park) to become refreshed to cope again, that what ART focuses on among other things. It therefore becomes an appropriate tool to analyse the Song and to take cognisance especially of a similar embracement of nature (and notable appreciation of the four properties mentioned) and its uplifting effects. As the Song does not elaborate on the causes of tension, because of its predominant interest in the phenomenon of love, it neither elaborates on the focused activities of the lovers after their natural retreats. These are assumed (implied) ${ }^{5}$ as the Song constantly meanders to and fro between mundane work/living space and sublime nature. What is clear already and will be elaborated on later is that nature in the Song becomes a safe haven to escape to, to enjoy love and life and to a limited extent, even contemplate on the gift of love.

In what follows the focus will first be on a rather lengthy explanation of ART to introduce this theory, followed by a reading of the Song through the lens of ART.

\section{Attention Restoration Theory}

\section{What is Attention Restoration Theory?}

ART addresses the problem of directed attention fatigue. 'Involuntary' attention can put the voluntary or directed (psychological) attention mechanism at rest. This happens markedly (but not solely) within natural settings that are both wild (e.g. reserves) and domesticated (e.g. gardens). Cognitive depletion becomes substituted with cognitive restoration and leads to a replenished state of mind so as to function effectively. Notions such as 'being away,' "'soft' fascination," 'extent' and 'compatibility' aptly describe the human: nature relationship, and function as descriptive properties that natural settings require to enhance the restorative experience. This, in a nutshell, is what ART comprises. But where does it come from, has it been empirically verified and where does this research nowadays incline to?

\footnotetext{
4 This does not mean that only stressful situations drive the two lovers to nature; the sheer enjoyment of being young and in love is understandably also a positive motive to enjoy the beauty of nature, wherever and whenever.

5 One could argue that the reflection on love itself (Song 8:5-7), the only didactic/philosophical part in the Song and regarded by many as its climax, is an example of 'focused' activity.
} 
Stephen and Rachel Kaplan, who pioneered the development of ART, reach far back into our evolutionary history to describe humans' natural, intuitive preference for certain natural areas (1989:1-116). ${ }^{6}$ Human beings store and process information par excellence and notably that what they see (1989:4), to enhance their survival. They instantaneously and unconsciously (1989:38) "take in" their immediate environment and make judgements about its fitness (or not) for their purposes. It has been empirically verified that we (almost universally - 1989:115) prefer environs that are "parklike or woodlawn or savanna" which are safe and provide free movement (1989:48; see also Frumkin 2001:236), ${ }^{7}$ aptly reflecting our early hominid history. ${ }^{8}$ Our preferences have also been shaped (nowadays) to choose for a balance between human influence and nature (1989:29, 31), for instance an attractive park instead of an industrial area. To explain our preferences theoretically the Kaplans developed a so-called preference matrix. Those spaces that we choose need to be ordered, understandable, be interestingly complex and even contain some element of mystery. ${ }^{9}$ The preference matrix has become informative for understanding the (ART) properties of being away, 'soft' fascination, extent and compatibility but cannot be transposed blindly onto these. ${ }^{10}$ Even so, it provides good insight into our spontaneous resonance with nature, the latter being the healing 'therapist' for our psycho-physiological well-being, and to restore attention burnout.

In developing ART specifically, the Kaplans (1989:179) became inspired by one of the founders of modern psychology, William James (1892). James distinguished between voluntary attention and involuntary attention. The first requires effort and deliberate focus whilst the second does not, for instance when one becomes excited and fascinated by strange, moving, bright and pretty things, wild animals, blood and so on. The Kaplans preferred to call James' voluntary attention 'directed attention,' and it is this mental mechanism that can easily become fatigued and in need of restoration (1989:180). The fact that it is prone to fatigue indicates that it is a limited resource (Kaplan \& Berman 2010:43) and most probably had adaptive value for early humans: "Just as wild ungulates cheerfully consuming a patch of delicious foliage look up intermittently (reducing the likelihood that

6 Although they intend to be inclusive with their study on human exposure to nature, they focus predominantly on flora and not fauna (Kaplan \& Kaplan 1989:2). This is probably to prevent their focus from becoming too encompassing.

7 What immediately comes to mind and needs further research is the (cultural) preference for deserts (including snow/ice 'deserts' in the poles) and jungles (admitted by Kaplan \& Kaplan 1989:95).

$8 \quad$ Water availability contributes to survival choices apart from its aesthetic attraction (Kaplan \& Kaplan 1989:9).

9 The preference matrix can be schematically presented as follows:

$\begin{array}{lll} & \text { Understanding } & \text { Exploration } \\ \text { Immediate } & \text { Coherence } & \text { Complexity } \\ \text { Inferred/predicted } & \text { Legibility } & \text { Mystery }\end{array}$

The first domain of 'immediate' experience of a preferred environment should have both an 'understanding' and 'exploration' component to address these two basic human needs. To 'understand' requires coherence or 'order' and to be able to 'explore' implies (interesting) complexity. The 'inferred' domain indicates more needed information (Kaplan \& Kaplan 1989:52) and for 'understanding' legibility or clarity ("easy to understand and remember" - 1989:55) is required and for 'exploration' mystery signifies to be almost drawn into another world.

10 In a personal conversation with Judith Burch (2012:45) Rachel Kaplan expresses the differences as follows: "Preference seems to be a set of evolutionary inclinations that support safe exploration... Restoration seems to be based on environments where there are things that hold one's attention without effort... From our perspective the two concepts focus on different circumstances". For instance, in evolutionary times involuntary attention ('fascination') was necessary to survive, now it helps restore directed attention, the modern 'surviving mechanism.' See also next footnote. 
anyone could sneak up on them), being too preoccupied to scan for potential hazards would also have been dangerous for our ancestors" (2010:45). ${ }^{11}$ This mechanism that helps us to focus on that which is important (e.g. our daily toil) and not necessarily interesting (e.g. bombardment with multimedia adverts, attention grabbers, etc.), allows us to conduct our executive functions (e.g. fixing attention) and self - regulation (e.g. controlling our emotions), in short to be effective (2010:44). If it becomes depleted people make 'human errors', become impulsive, impatient, distractible, irritable, aggressive and anti-social (Kaplan \& Kaplan 1989:181; De Young 2010:16). Directed attention fatigue is not the same as stress. Stress implies in a certain sense a 'looking forward,' developing anxiety because of inadequate resources to meet certain demands, of which the onset is swift and prompts the sufferer to look for help from other people. Attentional fatigue 'looks back' at a prolonged period of time of cognitive depletion and the sufferer prefers to avoid other people. Depleted attention can, however, contribute to stress as (another) limited resource leading to psycho-physiological malfunctioning (Kaplan 1995:172, 176-178). In order for the directed attention mechanism to replenish itself it needs the help of the involuntary attention mechanism or also referred to by Stephen Kaplan as 'fascination' (1995:172). 'Fascination' inhibits the bombardment of stimuli aimed at the directed attention mechanism. It does so by redirecting the focus of the mind to become effortlessly and automatically absorbed in interesting stimuli such as beautiful sunsets, water features, cloud formations, blooming plants, singing of birds and so on. It allows the mind to wander effortlessly and it enhances reflection. Whilst doing this the directed attention can come to rest. It is interesting that the two attentional mechanisms also have different neural signatures allowing different sets of neurons to function and rest in alternate fashion ${ }^{12}$. 'Fascination,' however, needs to be 'soft' and this is achieved markedly (but not solely) by exposure to natural environments. 'Hard fascination,' even though it might seem relaxing as by watching a sporting match on television for instance, is too attention-demanding and again taps into directed attention (Kaplan \& Berman 2010:49). But do all natural environments enhance 'soft fascination' and is the latter the only needed property to forge the required human: nature relationship for restored attentional abilities?

Natural environments need not only refer to pristine natural reserves far away but can be your own suburban garden. The Kaplans aptly refer to the latter as 'nearby nature' (1989:150 - 174) and it obviously includes small parks, courtyards or other green areas situated in the heart of major cities. A large reserve and a small Japanese garden can have the same positive effect on people, depending whether they meet the properties of being away, soft fascination, extent and compatibility. These properties overlap in some facets and create in synergy a restorative experience. Being away or 'getting away from it all' (the familiar term more than often used) implies not only to distance yourself physically from your daily, over-familiar working and home environment but to also conceptually experience yourself in 'another world.' It implies to be exposed to "cognitive content different from the usual" (1989:189). 'Soft' fascination has been touched upon already and refers to the 'undramatic' (Kaplan 1995:174) capturing of our attention by beautiful natural scenes but nevertheless allowing the mind to wander. Fascination easily transforms into the spiritual/religious experiences of awe and wonderment, aligning and adjusting our thoughts

\footnotetext{
Involuntary and directed attention switched roles in modern times (Kaplan \& Berman 2010:48).

2 "There are also neural data showing ... directed attention and involuntary attention may have some different neural foci ... directed attention may have more similarities to top-down attention, whereas involuntary attention would be more related to bottom-up processing," suggesting different brain regions for these different attention types (Kaplan \& Berman 2010:47-48).
} 
to an unseen blissful world (Kaplan \& Kaplan 1989:195, 197 referring to W James). Extent is characterised by coherence or interrelatedness of different natural objects forming part of a meaningful whole (order) and helps to easily form a cognitive map thereof (S Kaplan 2001:3-5; De Young 2001:18). Extent also includes a rich content or scope indicating that there is more to explore and discover than what meets the eye. It implies an openness and connectedness also to something (conceptually) larger, a greater reality or 'other world,' or in the Kaplans's own words: "Certainly, many gardeners feel a relationship to a force or system that is larger than they are and that is not under human control" (1989:191). The feeling of connectedness to some larger scheme of things evoked by extent, seemingly resonates with the previous two properties. Compatibility refers to the matching of the environment with one's purposes and inclinations (1989:185). If one wants to go for a relaxing stroll in nature and try to do it in dense thickets, it becomes rather meaningless. Usually, however, people 'fit' and adjust easily in nature with "...a special resonance between the natural environment and human inclinations" (1989:193). This makes sense, because this is where we come from and where we belong. People avail themselves of different roles when they resonate with nature: predators (hunting and fishing), locomotors (hiking, canoeing), domesticators (gardeners), observers (bird watchers) and survivors (building fires and shelters). Although some researchers emphasise 'control' over nature to describe these diverse roles, enjoyment of nature is the verified better answer (1989:194). It is especially these properties that provide fruitful grasps ('handles') of the 'natural retreat' sections of the Song of Songs. Their conspicuous presence in the Song shows that its author(s) had a fine and intuitive grasp of the natural resonance between humans and nature, exemplified by the two lovers' 'need' for nature to enhance their overall well-being and happiness. The Song's preoccupation with love understandably allows it to pay little attention to some socially stressful situations leading to emotional and cognitive fatigue and similarly their return to this 'real' (harsh) world after their retreats. Nature's uplifting powers can, however, be assumed to have benefited them similarly to how it is doing today with people globally, as the few empirical examples to follow will demonstrate.

Exposure to nature is not the only remedy to address directed attention fatigue. Sleep can produce similar restoration effects, the intake of glucose has also been shown to have positive effects on improved performance and likewise the practice of meditation (Berman et al. 2008:1211; Kaplan \& Berman 2010:52-53; S Kaplan 2001). Meditative and (nature) restorative experiences strive for the same goal, namely attention replenishment, but via different routes. Meditation is a disciplined, trained and mentally effortful exercise to achieve a passive state of mind, whilst a restorative experience in nature needs no training and is mentally effortless and relaxing throughout (S Kaplan 2001:2, 12) ${ }^{13}$. Moreover, nature is all around us and available to everyone, even in the midst of our massive 'concrete jungles', the big cities that are home to most people nowadays. And nature's healing benefits come free.

\section{The Empirical Foundations of ART and the Way Forward}

Frumkin reiterates the Biophilia Hypothesis that humans are naturally attracted to animals, plants, landscapes and wilderness, explaining our intuitive preferences for certain habitats (open, tree-studded, with water) that promise safety, survival and our well-being

13 See also the study of Herzog et al. $(2010: 395,416)$ confirming the restorative value of spiritual settings (houses of worship), enhancing internal peace, meditation and reflection. 
(2001:236). Nature functions not only as a setting, but also as a 'dynamic partner' in wellbeing (Berger \& McLeod 2006:81). Berger and McLeod (2006:83, 85) indicate how this insight was thoroughly grasped by our traditional forebears. They used nature as a sacred space along with rituals that resonate with natural forces, during their regular healing ceremonies. This age old insight of nature being 'good' for us has also been embraced by ART. Empirical studies testing and confirming ART and the health benefits that nature provides, abound. A few illustrative examples of healthy people maintaining their health, as well as those that suffer from more severe psycho-physiological disorders, ${ }^{14}$ will be highlighted. Interestingly, exposure to nature alternates between 'real' nature (e.g. walks in parks) and 'virtual' nature (e.g. looking through windows, photos/videos/murals of nature).

De Young (2010) writes appreciatively on ART and proven empirical studies to restore 'mental vitality' through the simple act of regular walking in a natural setting. 'Mental vitality' (2010:13) is his circumscription of the capacity to function effectively, both in problem solving, planning, restraining behaviour as well as managing emotions (i.e. executive and self-regulation; see Kaplan \& Berman 2010:44), that become fatigued in modern city life. To enhance mental vitality he recommends "simply to walk, to walk outside, to walk regularly, and to walk surrounded by and mindful of everyday nature" (De Young 2010:21). ${ }^{15} \mathrm{He}$ also emphasises that more research on the intensity, quality and amount of time of nature exposure ('dose'), needs to be done (2010:20). Rachel Kaplan (2001) did a study on views from a window (one of many done by others as well) that indicated restorative effects when natural elements are in sight. She regards the view from the window as a 'micro- restorative experience' - "The glimpse of the world beyond afforded by the window view can quickly transport one elsewhere ... to distant places and thoughts" (2001:511). Her survey comprised the analysis of both verbal feedback and of visual material (photos of apartment views) of a sample of six low-storey apartment communities. Her findings were that satisfaction and a feeling of well-being resulted for those who had natural views from their windows, but satisfaction was limited for those who had views only of buildings. Interest in sky views and of the weather was not that significant. The benefit from such views is that they can be brief, happen daily (as compared to a vacation in the wilds), effortless and safe (2001:508, 509, 511). Another study focusing on healthy people was conducted by Felsten (2009) on college students, who had to imagine themselves being cognitively fatigued and had to perceive where to take a restorative (indoors) break. A perceived experience is a good indicator of an actual one $(2009: 166)^{16}$. They were exposed to four views: no views of nature, a window view of nature (but mundane nature), a large ${ }^{17}$ mural of a natural scene and another large mural of a natural scene with a waterfall. ${ }^{18}$ As expected these simulated scenes were rated highest to

14 Frumkin (2001:237) interestingly notes how psychiatric in-patients would rather destroy mural art of abstract or symbolic representations than nature scenes such as landscapes.

15 On a lighter note, “...next time colleagues show up at your door ... rude and irritable ... tell them to take a hike. Then go take one ourselves" (De Young 2010:21). Pearson and Craig (2014:2), however, question the rather 'undervalued' argument of perceived restoration as equalling an actual natural restoration.

17 Larger mural scenes of nature have been found to provide an improved sense of 'immersion' or to be captivated by a vivid sense of imitated reality (Felsten 2009:162, referring to De Kort et al.). Berto (2005:255258 ) interestingly found that images of geometrical (non-environmental) patterns, although effortless to view, are not innately interesting and restorative, because they do not contain the properties of ART.

18 Researchers often accept almost ipso facto that the presence of water and certain colours (e.g. green and especially blue) enhance restoration but this may be a premature conclusion and needs more research (Michaelis 2011: 6-8, 32). See also footnote 8. 
lowest in reverse order concerning their restorative potential. Even the window view of real (but mundane, depicting late fall) nature compared to the murals, was rated low. Felsten emphasises (2009:166), however, that murals should supplement and not replace real nature when it comes to campus design and lay-out for restorative purposes.

Moving on to a study of the positive effects that tree-view windows had on hospitalised patients, after they had undergone a cholecystectomy (gall bladder surgery), Ulrich in his short, but often quoted article of 1984, confirms the healing benefits of nature. The patients surveyed were split into two groups, those with window views of nature (trees) and those with views of a brick wall. Ulrich concludes as follows: "...patients with the tree view had shorter postoperative stays, had fewer negative evaluative comments from nurses, took fewer moderate and strong analgesic doses, and had slightly lower scores for minor postsurgical complications" (1984:421). Although Ulrich focuses on stress and notably its physiological effects and reactions apart from affective reactions (Stress Recovery Theory, SRT) many researchers are convinced that SRT can be combined with ART in a general framework (e.g. Hartig s.a.). An example of such a combined view was done by Chang et al. (2007) on a group of Taiwanese students where their psychophysiological responses were measured, after viewing visual images of natural scenes representative of the four properties of being away, fascination, extent and compatibility. Psychological restoration was measured according to the Perceived Restorativeness Scale (PRS) and the physiological restoration measured by electromyography (EMG - measuring facial muscle tension) ${ }^{19}$, electrocephalography (EEG - decrease in alpha brain wave activity indicative of restoration) and blood volume pulse (BVP - lower blood pressure indicative of restoration). Psychological and physiological restoration matched after exposure to visual natural environments, confirming their 'restorative-leisure benefits' (2007:483).

Apart from benefitting the healthy or those hospitalised for physical reasons, exposure to nature has great healing potential also for those with psychological disorders. This was confirmed in a study on children diagnosed with Attention Deficit Disorder (ADD) by Taylor and Kuo (2009). ${ }^{20}$ ADD is regarded not so much as an attention deficit but rather a (directed) attention inconsistency or a severe susceptibility to attentional fatigue (2009:402, $403,407)^{21}$, but still leaving involuntary attention intact. Typical symptoms apart from attentional inconsistency leading to poor academic performance, are low self-esteem, anxiety, depression, aggressive and anti-social behaviour. In their study Taylor and Kuo exposed ADD children to three different environments after being fatigued (by building puzzles). They had to go for a walk in the park, a walk downtown and a walk in the neighbourhood, and were afterwards tested (inter alia with the favourite Digit Span Backwards measure, to determine the level of focused attention). The park walk ranked highest and its effect is roughly equal to two doses of ADD medication. A mere twenty minutes seemed to be quite enough exposure time for nature to be effective. Taylor and Kuo conclude as follows (2009:402): “Doses of nature' might serve as a safe, inexpensive, widely accessible new tool in the tool kit for managing ADHD symptoms." How lasting the effect of these 'nature doses' is, still remains an open question (2009:407). A nature walk also benefits those who suffer from Major Depressive Disorder (MDD). Short-term

19 Chang et al. (2007:483) point out that there are different views on EMG findings; some studies regard reduced EMG readings as indicative of reduced stress, whilst others hold exactly the opposite view.

20 This study intended to be more objective than an earlier study (Taylor et al. 2001) relying mostly on parent feedback.

21 The right frontal lobe, which plays a key role in directed attention, is also smaller in ADD children (Taylor et al. 2001:56). 
memory and mood were measured (with the Positive and Negative Affect Schedule [PANAS] and Backwards Digit Span [BDS]) of twenty adults with MDD (Berman et al. 2012). Memory and mood were measured first. Then participants were asked to recall a very negative autobiographical event that usually prompts rumination on this event, exacerbating negative mood and impairment of short term memory (2012:301). Hereafter they were asked to take a 50 minutes walk in a nature setting and were measured again. A week later the procedure was repeated except that this time the walk took place in an urban setting. The result was as follows: "Working memory capacity and positive affect improved to a greater extent after the nature walk relative to the urban walk. Interesting, these effects were not correlated, suggesting separable mechanisms" (2012:303). Even when ruminating on the negative personal event they seemed to think about it more 'adaptively' (2012:304) during the nature walk. Berman et al. (2012:304) also end their discussion with the same uncertainty mentioned previously, namely the lasting effects of nature exposure that needs to be researched.

A few interesting further applications are the following. In a 2012 study by landscape architect $^{22}$ Judith Burch, she utilised ART (and also favours a combination with SRT, 2012:3), principled insights from architecture in general and that of dementia garden design specifically (along with input from Dementia [Alzheimer] specialists), to design a dementia garden in the courtyard of Schowalter Villa Retirement Centre. She hopes that her developed framework will assist in the design of therapeutic gardens in general, besides only dementia gardens (2012:70). Examples of exposure to real nature and virtual nature have been noted above but the debate on the benefits of both continues. Mayer et al. (2009) support real nature, but De Kort et al. (2006), admitting the absence of all the senses in a virtual environment (2006:310), offer the substitution of virtual nature for those who cannot experience real nature (e.g. the hospitalised). However, they emphasise the requirements of 'immersion' (a captivating, inclusive, surrounding and vivid imitation of reality; 2006:311) and 'presence' (the feeling of 'being there'; 2006:311) when utilising modern media technology for restorative purposes. 'Presence' (through 'physical space', 'naturalness' and 'engagement') links nicely with the Kaplans' four properties noted above. The manipulation of screen size (larger) when a natural film was shown enhanced 'immersion,' and although not that overwhelming, 'presence' was achieved to limited extent. Virtual nature can therefore come very close to real nature with the "...intelligent and educated use of media technology" (2006:318). But the quality and intensity of exposure to nature applies just as much to real nature, so much so that people can and should "...cultivate their sense of fascination and wonder when they are in natural environments" (Sato \& Connor 2013:203).

It has hopefully become clear that ART is a sound theory with firm empirical support. The appreciation and utilisation of nature as 'partner' in our overall well-being is timely, acknowledging our deep-seated bond with nature. We are part and parcel of nature and cannot live apart from it. The fruitful application of ART has dovetailed into several fields of interest, namely medicine, psychology, architecture, town planning, environmental studies, education, etc. Is it only in the last decades that humans have discovered the healing effects of nature - or did our ancient forebears (intuitively) know that nature is

22 Another very interesting study from the field of architecture is that of Hägerhall (2014:15) on fractal geometry. 'Fractals' refer to (neurologically) universally preferred forms that bias us to choose certain landscapes/visual outlines above others - "A fractal has the characteristic of being self-similar, i.e. the same pattern will appear again and again when a fractal object is viewed at increasingly fine magnifications." 
good for us? It is time to take a closer look at an ancient book of love, the Song of Songs, and how it embraces nature.

\section{Reading the Song of Songs through the Lens of ART}

Date (around the Hellenistic times) and authorship (probably male-authored) ${ }^{23}$ do not necessarily contribute to our better understanding of the Song of Songs, but rather to grasp it as timeless, universal love poetry. Exum (2005:1) describes the Song as follows: “...a long lyric poem about erotic love and sexual desire - a poem in which the body is both object of desire and source of delight, and lovers engage in a continual game of seeking and finding in anticipation, enjoyment and assurance of sensual gratification." This "plain sense' reading of the book makes it the most unbiblical book in the Bible (Meyers 1988:177). Its open celebration of sex between two young people who do not seem to be married, along with the absence of the naming of the Hebrew national god, indeed makes it a strange book in the biblical canon (Fontaine 2001:126). Its metaphoric character understandably evokes many other readings than that of erotic loveplay, for instance the well-known allegorical reading, ${ }^{24}$ with its disdain for the flesh (LaCoque 1998:11, 67). But the Song is not an allegory with some esoteric meaning (Exum 2005:76). It is neither a cultic-mythological enactment or ritual ${ }^{25}$ as Pope (1977) for instance would contend, of some dying and rising Ancient Near Eastern fertility god, although it does 'echo' some 'fertility survivals' (Fontaine 2001:127). Neither does the Song have a plot (a movement from $\mathrm{A}$ to $\mathrm{Z}$ ) but is rather meandering, its larger and smaller units ${ }^{26}$ in constant circularity (Exum 2005:45). This also discredits the so-called dramatic theory with its many variants (2005:8). That the Song is subversive is clear from its uninhibited celebration of the body. It also subverts patriarchy with the young woman following her own mind, ${ }^{27}$ collapses the divide between classes and appreciates nature/earth in its own right by acknowledging it as 'kin' (Viviers 2001:144, 148-152; see also Fontaine 2001:127-141). On the role of nature Exum (2005:13) says: "Nature in all its glory reflects and participates in their mutual delight" and so emphasises nature's 'agency' (see Introduction) that is of interest in this contribution. In what follows examples of 'real' ${ }^{28}$ natural retreats from the Song and how nature contributes to the two lovers' well-being, will be highlighted.

The duet of chapter 1:15 - 17 may be concise, yet replete with repetitions. The man almost stammers "How beautiful you are, my darling, Oh, how beautiful..." (v. 15) and she reciprocates almost verbatim "How handsome are you, my lover, Oh, how charming..." The reiteration further of 'our' bed, 'our' house and 'our' roof aptly expresses their oneness

The Song's unity and cohesiveness is indicative of a single authorship with little editing (Exum 2005:35).

"The problem with allegorical interpretation, as well as its typological and parabolic variants, is apparent. It is not verifiable, and it is arbitrary. No agreement exists among allegorical interpreters." (Exum 2005:76; see also p. 250 and LaCoque 1998:166).

25 Exum (2005:64) for instance, is adamant that the Song is a literary and not a ritual text.

26 Exum (2005:39) provides different scholars' structural divisions of its larger and smaller units, making up the meaningful whole of the Song.

27 Despite the excitement amongst feminists, Exum (2005:27) warns that the Song of Songs may not be that liberative for women, as she abides by convention -"she gives and he takes." So also Clines (1995) and Polaski (1997), who both question her independent agency as a woman, as she seems to be nothing more than a male fantasy who has internalised the male gaze, and is therefore still like clay in the hands of men (at least her lover).

28 It is not always clear whether nature functions as a 'real' setting or whether it is only metaphoric and therefore imaginary for one of the lovers (e.g. 6:2-3), confirming Gerleman's (1981:189) remark that there is a thin dividing line between reality and metaphor in the Song. 
(Barbiero 2011:80). Her 'eyes are doves' signals messages of love (Barbiero 2011:79 following Keel) and acknowledges the dove as an ancient and modern symbol of love (Exum 2005:112). And this is exactly the aim of this natural retreat, a safe, private and intimate natural spot for the consummation of their love, characterised by a green carpet of ground coverage and shaded by a roof of the green foliage of cedars and cypresses. ${ }^{29}$ Trees convey security and stability in the Song, says Munro (1995:86) and the two lovers' choice of this 'secure bower' (Munro 1995:86; see also Longman 2001:108) confirms the age-old universal human choice of natural retreats to be safe, and in this instance secluded from the controlling and censoring society (e.g. 1:6; 8:8-9). It is to this section that Fontaine's (2001:130) words, "get away from it all" (see again R Kaplan above), mentioned in the Introduction, and encapsulating the property of 'being away', refer. Being away also of the daily toil and demands of society is what brings these two lovers together here in this idyllic "other world of love." Compatibility has been touched on already, they want to celebrate their love in this ideal, natural 'love nest' or 'house' on their verdant bed. Fascination is expressed not only for each other's natural beauty and attractiveness, but also for the lusciousness of green, fertile nature. Green is not only seen on the ground but also in the impressive canopy of cedars and cypresses, accompanied by refreshing smells (Longman 2001:108). Springtime permeates the whole of the Song with its irresistible overwhelming of all the senses, keeping the attention (softly) captured. And although these few lines of poetry are terse, they are expressive also of extent. Fontaine (2001:134) captures the richness of nature and the transportation of the lovers also into 'other worlds' as follows: "The 'green couch' is an index of all that may be conveyed by the color ${ }^{30}$ of growth and a textual link to the life-force ${ }^{31}$ of Earth intensely at work in the real world..." But both the couch ('ereś instead of miškāb evoking luxury; see Pr 7:16, Am 6:4-6; Barbiero 2011:81; Fox 1985:106) and the references to cedar beams (qōrâ -2 Chron 3:7) and cypress rafters (rạhit t) - the building materials of palaces and temples (Barbiero 2011:81; Gerleman 1981:113, 114; Rudolph 1962:128) - evoke a heavenly world of bliss, in which all lovers usually find themselves. ${ }^{32}$

Whereas the previous retreat seems to take place in 'far away' (wild) nature in the woods, the retreat in the spring song, Song 2:10-13, is envisaged in 'nearby' nature, the vineyards and orchards of fig trees. However, wild nature is also dispersed throughout the cultivated fields, with wild flowers starting to bloom and where the voice of the migratory turtle dove can be heard (v.12; Pope 1977:396, Longman 2001:121), now that spring has arrived. Rudolph (1962:134) might be exaggerating somewhat by calling this spring song "das schönste Naturlied im AT" but it is indeed a beautifully composed poem appealing to its audience then and now. Song 2:10-13 forms part of a larger unit 2:8-17 that is neatly structured chiastically: it commences with the invitation of the 'gazelle' lover (vv. 8-9), followed by two invitations (vv. 10-13; v. 14) and closes once again with the gazelle metaphor (Viviers 2001:146). It is framed by an inclusio with the affectionate invitation "Arise, my love, my fair one, and come away" (vv. 10, 13). These words in themselves

\footnotetext{
29 LaCoque (1998:80) articulates as follows: "sans toit ni loi" (without roof or rule), unmarried!

30 See again footnote 18 for the emotive meanings of colours (green and blue) in nature for which humans might have an intuitive attraction.

31 Both Fontaine (2001:134) and Arbel (2000:94) see in the 'greenery' some subdued allusion to procreation, otherwise almost absent in the Song.

32 Murphy (1990:135) is therefore not correct that kingly fiction (1:12-14) has yielded to rustic shepherd fiction. The skillful poet retains both genres.
} 
form a chiasm (Murphy 1990:140). The invitation to "get away from it all",33 is expressed emphatically by the words $l^{e} k \hat{\imath} l \bar{a} k$, to be translated 'leave,' 'come out' and not merely as 'come' (Barbiero 2011:111). The property of compatibility of this natural breakaway is not merely the enjoyment of the arrival of beautiful, life-pulsating spring but also an invitation to intimate lovemaking. Everything else in nature 'blooms' and likewise our "vineyards [that] are in bloom" (v. 15; see also the refrain of mutual belonging in v. 16). If the lovebird sings, humans should echo (v. 12). Springtime here heralds the exuberant season of love in encompassing ways (Munro 1995:91; Exum 2005:127). Being away in nature and imitating its celebration of new life and love already extend to 'other worlds.' Fascination with the spring setting is up front, or in the words of Barbiero, the two lovers are to experience and enjoy "... an epiphany of colours, sounds and scents" (2011:112; see also Longman 2001:122). Fascination and wonderment lure towards another, greater reality, which brings us to the full extent. That this spring scene is rich in content and scope, interesting and captivating is clear. It enhances 'connection' to something larger and also reflection, albeit in this instance mostly on the phenomenon of love. Connectedness comes to the fore on two levels, firstly as an intuitive human connectedness to nature ${ }^{34}$ which the Song spontaneously portrays in its collapsing of the (mostly Western) divide between human and nature. Humans become nature through metaphor (e.g. the lover as gazelle [vv. 8-9, 17]; the 'beloved' as dove [v. 14]; human 'bodies' become blooming vineyards [v.15]; Barbiero 2011:110) and nature humanlike through personification (turtle dove 'singing' v. 12). ${ }^{35}$ When 'incorporating' the beauty of nature humans become 'one body' with nature (Viviers 2001:150), and so become linked to the life-force permeating the earth. A further level of connection implies a deep-seated (conceptual) awareness also of the ultimate life-force, a 'transportation' to a greater whole and the human place in the bigger scheme of things. ${ }^{36}$ Towards the climactic end of the Song (8:6-7) we do find a contemplation on the essence of the love force itself.

Whereas with the previous 'going down' to the gardens (6:2) there was doubt whether it was 'real' or imaginary, the 'going down' (same verb yārad) or retreat ('being away') to the nut grove in 6:11 points to "...a real visit to a real garden..." (Murphy 1990:179). Gerleman (1981:189), however, reminds us that the border between reality and metaphor in the Song remains thin and permeable. As before, life-pulsating nature becomes the place and metaphor for the lovers' anticipated intimate union (Longman 2001:185; Barbiero 2011:352), the latter which is the purpose (compatibility) also of this 'breakaway.' Song 6:11-12 thus reminds us of the earlier spring retreat, 2:10-13, as well as 6:2-3 where nature elements serve to depict the woman or man, depending who speaks. In regard to the latter it is not clear whether the man or woman speaks - is nature here the vehicle for the man's attractiveness capturing the woman's fascination whilst exploring his body (e.g. Longman 2001:185), or does nature 'image' suggest the desirable woman (e.g. Barbiero 2011:350-

33 These words are put into the mouth of the man by the woman, and can also reflect her eagerness to escape, in ART jargon, the boring or even depressing, over-familiar cognitive content of being confined 'indoors', especially when compared to the man who is free to go about as he wishes.

34 Barbiero (2011:109) points out how chiasms and enjambment (vv. 10-14 to v.15) subtly undergird "the integration of the lovers into nature." Fox (1985:113) refers to "in our land" (v. 12) as no national bond but "the bond of the individual to the earth ... of the individual spirit to nature."

35 Agency applies to nature as a living 'subject' in its own right (Viviers 2001:147) and not a human characteristic only.

36 "The moving aesthetic experience of wonder and awe at Nature's new spring face that the lover anticipates" (Song 2:10-13) unmistakably also points to an overwhelming mystical experience (Landy 1983:178)" (Viviers 2001:152-3). 
$351) ?{ }^{37}$ For the purpose of this article it would not really matter which one of the two speaks to encapsulate the positive effects of human exposure to nature. I follow Barbiero (2011:351; see, however, Exum 222-224 for strong arguments for both sides), who regards the man as the speaker. The imagery of especially the budding vines and pomegranates describing the woman elsewhere in the Song (e.g. 4:13; 7:9) makes good sense also here in the man's mouth. His fascination with the sights (verb $r \bar{a}$ 'āh repeated twice in v. 11) and smells of nature in bloom, including also the greenery of the valley, ravine or stream-bed ( ${ }^{e}$ ibey hanāhal; Pope 1977:579, 582) signalling new life (see colour 'green' above), simultaneously also calls to life his 'blossoming/budding' beloved, to further capture his mind. Barbiero (2011:352) sees in her, 'heaven' (the preceding 6:10) coming down and becoming incarnated in the earthly garden - “...in this simple young woman, heaven is present because love is present." Fascination and extent (linking to the celestial world) go hand in hand. Of all the examples focused on thus far, 6:12 is the clearest example of extent, of nature acting as the catalyser to let the mind wander into a different (conceptual) world. Unfortunately verse 12 is also the most enigmatic verse in the Song, due to the corrupt Masoretic text, and therefore leading to as many emendations as there are scholars who try and make sense of "I do/did not know my soul (it) set me chariots of my princely people" (e.g. Pope's literal translation [1977:584]). Exum emends economically (2005:211, 224-225) ${ }^{38}$ to arrive at the following translation: "I did not know myself, carried off amid chariots with a prince" (and opting for the woman as speaker). Munro, who opts for the male speaker, translates: "Before I knew it, she set me among the chariots of my people, as prince," also retaining something of the royal fiction of the Song, the opulent and privileged world of kings, queens and nobles that the lovers often imagine themselves (e.g. 1:9-11; $1: 12-14 ; 3: 6-11 ; 6: 4-9)$. As before, Barbiero (2011:361) brings the heavenly realm into focus. He argues that 'chariots' echo the chariots of Israel which transported Elijah into heaven ( $2 \mathrm{Ki} \mathrm{2:12).}{ }^{39}$ The same numinous power in action here is personified in the woman and explains the effortless ("Before I knew it...," v. 12) and overwhelming transportation into 'another world.' Whatever meanings diverse emendations might evoke, it is clear that nature has the power to transcend the mind to fascinating other worlds of meaning and signification.

Song 7:12-14, aptly enclosed as a unit through inclusio (dôdî in 12a and 14d; Barbiero 2011:411), almost echoes 2:10-13 and seems like a deliberate repetition of 6:11 (Murphy 1990:187; see also Rudolph 1962:176). Here the woman entices her lover to come along to the fields, the henna bushes, the blooming vines and pomegranates. Abandoning the city in favour of nature is adequately demonstrated here. This love rendezvous happens in cultivated nature and not in the small villages/towns, as $k^{e} p \bar{a} r \hat{r} m$ is sometimes translated, instead of henna flowers (Pope 1977:645; Longman 2001:200; Exum 2005:240; Barbiero

37 Longman (2001:184 following Pope) points out that the nut imagery can represent both the male and female genitalia.

38 After correctly arguing against proper names such as Amminadab (e.g. LXX, the Vulgate and many commentators) and fully motivating her other choices, Exum (2005:213 notes h and i; 225) states: "But it is also possible, and seems more likely, that the woman is referring to a specific noble or princely man, her lover; compare Fox ('you've placed me in a chariot with a nobleman'); Longman ('my desire had placed me in a chariot with a nobleman'). This is the interpretation I have adopted here, reading mrkbt without the mater lectionis, as the singular, 'chariot', and ' $m$ ('with') for 'my ('my people')."

39 Longman (2001:187) refers to MJ Mulder who defends the idea of merkabah (chariot) mysticism, a late OT development reflected here, as the speaker goes into a trance-like state. Even though not that convincing, it remains interesting (very much so for the purpose of this article) that this verse constantly evokes 'otherworldly' meanings. 
2011:413). It therefore also calls forth the earlier getting away in Song 1:15-17. The city is a love-unfriendly place and jeopardises the lovers' privacy (e.g. 5:2-7; 8:1; Longman 2001:200; Barbiero 2011:413). The purpose (compatibility) of this retreat is not a simple garden tour but an erotic pleasure trip (Pope 1977:646), it leads to an erotic crescendo (Exum 2005:240; see also Longman 2001:200), where the young woman gives herself in love to her man: v. 12 “...there ${ }^{40}$ I will give you my love", v. 13 “....at our door is every delicacy, both new and old, ${ }^{41}$ that I have stored up for you, my lover." As before, fascination with the cycle of blooming nature mirrors, stimulates and enhances the blossoming and fulfilment of the love of the two lovers (Exum 2005:241; Munro 1995:119), eloquently articulated by Fox (1985:165): “The vine has blossomed, the bud opened, the pomegranates bloomed. The fruits of love are ripe for eating." Adding a new plant not mentioned before is the mandrake (love apple) filling the air with its characteristic fragrance, believed in the Mediterranean (and elsewhere) to have aphrodisiac potency ( $\mathrm{Gn}$ 30:14-16; see especially Pope 1977:648-9). A conspicuous wordplay or paronomasia is created between dôdî ('my lover,' vv. 12a and 14d), dôdîm ('caresses,' v. 13e) and dîdā 'îm ('mandrake', v.14 a) (see Barbiero 2011:411), contributing to the atmosphere of love and subtly linking nature and humans. The mandrake invites to love and the woman responds appropriately by giving her lover the 'choice fruits' (herself) she has saved for him (Fox 1985:164). The savouring of the delights of nature and of each other (Exum 2005:241) shows a progression in sensuality: "We pass from 'seeing' (v. 13b), to smelling ('fragrance,' v.14a), to eating ('fruits,' vv. 14b-d)..." (Barbiero 2011:411). Extent, leading to the entering of the wondrous world of love through nature has become clear, and is taken a step further according to Barbiero (2011:421) with his focus on the verb sappan, the 'saved/stored' 'choice fruits' ${ }^{42}$ of the beloved for her lover (v.14). Following Krinetzki he argues that șāpan also means 'hide' and therefore signals 'mystery.' Couples should always retain some 'mystery' for each other to be discovered in the exploration of their world/universe of love.

Moving to the closing unit of the Song (8:5-14), 8:5 as part of the smaller 8:5-7 is another example of the enjoyment of nature leading to some deep reflection on love itself. The two lovers coming from the wilderness on their way to Jerusalem, reminds of Song 3:6. Wilderness and apple tree imply both wild and cultivated countryside. Wilderness as place spells both danger and death but also the place where the forces of life and love ${ }^{43}$ can be sensed and therefore provides a fitting inspiration for the reflection on the force of love itself (vv. 6-7). Under the apple tree, ${ }^{44}$ ( $\check{s} \bar{a} m$ 'there' strongly emphasised; Barbiero 2011:449) has both erotic (see also 2:3, 2:5, 7:8; and 1:16-17 'love in the green' [Barbiero 2011:451]) and mythological overtones (Gerleman 1981:215; Pope 1977:663; Murphy 1995:191), and together with mitrappeqet ('leaning'; hapax), 'ôrartîka ('I rouse you' is erotic here - Munro 1995:84, 123; see also refrain of adjuration 2:7, 3:5, 8:4) and repeated verb hăbal ('conceive'), clearly signal the purpose of this retreat - lovemaking! Fascinated by the awe-inspiring environment and each other whilst 'dallying' (Exum 2005:249) in

\footnotetext{
$40 \quad \check{s} \bar{a} m$ (emphatic) carries both the meanings of place and time (Barbiero 2011:416).

41 A clear example of merism, even though the 'old' along with 'new' sounds somewhat strange.

42 Barbiero's (2011:420) interpretation of the woman as a personification of the Promised Land through her association with 'choice fruits' ( $m^{e}$ gādîm; see Deut 33:13-16), seems to be reading too much into this term!

43 Astarte, the goddess of love, one amongst many other divinities representing life's forces, is often associated with the desert (Barbiero 2011:146-147, 447).

44 Some commentators refer to this tree as an apricot (e.g. Fox 1985:167) but apples were well-known in Palestine (Exum 2005:114).
} 
nature as we have seen before, confirms the effect of the extent of this particular natural setting. It evokes the transference into other worlds and allows for reflection. When the woman thinks back of the lovemaking, conception and giving birth of the mother (of her lover) at the same place under the apple tree where they now find themselves, he is being born to her for a second time, this time for love! (LaCoque 1998:166 following Lys; Munro 1995:72; Exum 2005:249; Barbiero 2011:452). This retreat does not only transport them into their intimate private world of love but also the universal world of love of all lovers, where the power of love is astounding ${ }^{45}$ (v. 6-7). Song 8:6-7 is the climax of the Song and its only didactic/reflective part, which Exum (2005:245) succinctly recapitulates as "...love is experienced as astonishing, overwhelming, confident, undeterred, deep, and strong as death."

The last two verses of the Song, vv.13-14, let it end appropriately in the garden, as a reaffirmation not only of the value of the two lovers' love but also of nature itself. Nature becomes the final inspiring place and 'agent' to uplift these two lovers to higher worlds. Murphy (1990:194) correctly acknowledges the garden to be taken literally ('being away') but wrongfully denies its metaphoric overtones - garden is (as before) both place and women as expressed by her 'Kosename' (pet name), 'garden dweller' (Gerleman 1981:223; Fox 1985:176). And the purpose (compatibility) of this last retreat is an 'erotic imperative' (Exum 2005:261), expressed by both the man and woman in dialogue. He, along with his companions, wants to hear her sweet voice (v. 13; see again 2:14) and she wants him to return to her - the 'spice-laden mountains' like a virile young gazelle or deer. It is unsure whether the companions are the daughters of Jerusalem (so Munro 1995:110). It seems, however, more probable that they are the friends of the man in their dual role of competitors or supporters (see 1:7; 2:15; 3:7 ff.; Longman 2001:221) representing society (including the daughters of Jerusalem) (Barbiero 2011:496; Exum 2005:262). Fascination during this retreat comes to the fore through sound (voice of the woman), sight (the lively gazelle) and markedly through smell (taste and touch implied) of the women's delectable body, she being the mountains of spices (Murphy 1990:200). The latter recalls inter alia her breasts (4:6 - her mountain of myrrh and hill of incense; see also 1:13), she as 'garden' $(5: 12-5: 1)$ and her fragrant garments $(4: 11)$. The rich extent or scope of these natural elements takes the mind to far and exotic places from where these delicacies originate (Munro 1995:137). And it evokes the truth of the cycle of love that never ends. This comes aptly to the fore with the summons of the beloved to her lover with the word bārah. It usually means 'going away' but here in verse 14 it assumes the meaning of "take flight ...to me" (Exum 2005:262; see also Fox 1985:177). And so the Song ends open-ended, always playing love's game of hide and seek (Munro 1995:89; LaCoque 1998:190); and similarly, also our experience of nature, constantly stirred by it to wander into (conceptual) other worlds and always returning to it to be inspired anew.

\section{Conclusion}

The Song of Songs is not only a love-friendly book but markedly also a nature-friendly book. As it idyllically describes the phenomenon of love it simultaneously resonates with nature as a 'partner' in discovering and enjoying this gift of life. The two lovers' happiness is conspicuous as they break away to nature to escape stressful societal pressure or are

This acknowledgement of the power of love reflects the emotion of awe. Awe at its core has to do with hierarchy, of subordinates looking up to a powerful superior person, animal or phenomenon, in this case love (Keltner \& Haidt 2003). 
merely young and in love. It is in and with nature that they pursue and enjoy their love, become fascinated and reflect on the force of love and life. The Song intuitively adheres to all four ART properties that nature requires to contribute to humans' overall welfare: 'being away' (new cognitive content of nature exposure), compatibility (nature as ideal setting for love), fascination (especially with blooming/budding spring time) and extent (nature's rich content to facilitate mind-wandering and contemplation). Their small intimate universe connects them to the greater world in which all lovers find themselves. In similar vein our ancient forebears (e.g. great thinkers) realised the shaping and replenishing value of villas, gardens and nature and enhancing contemplation and overall well-being.

Attention Restoration Theory is a sound theory with a firm empirical basis. It provides an attractive explanation of how the human mind replenishes itself to ensure overall human well-being. Where it initially endeavoured to explain directed attention fatigue, it became applied and extended to diverse fields (medicine, architecture, town planning, environmental studies, education), and notably emphasises the overall 'healing' effects of nature. Nature is acknowledged and embraced as a 'partner' in this healing process and confirms our deep-seated bond with the natural world, which is all around us (even in the big cities) and of which we are an integral part.

\section{BIBLIOGRAPHY}

Arbel, DV 2000. "My Vineyard, my Very Own, is for Myself," pp. 90-101 in Brenner, A \& Fontaine, C (eds.), The Song of Songs. The Feminist Companion to the Bible (Second Series). Sheffield: Sheffield Academic Press.

Barbiero, G 2011. Song of Songs: A Close Reading. Tr. M Tait. Supplements to Vetus Testamentum, 144. Leiden: Brill.

Berger, R \& McLeod, J 2006. Incorporating Nature into Therapy: A Framework for Practice. Journal of Systematic Therapies 25(2):80-94.

Berman, MG, Jonides, J \& Kaplan, S 2008. The Cognitive Benefits of Interacting with Nature. Psychological Science 19(12):1207-1212.

Berman, MG, Kross, E, Krpan, KM, Askren, MK, Burson, A, Deldin, PJ, Kaplan, S, Sherdell, L, Gotlib, IH \& Jonides, J 2012. Interacting with Nature Improves Cognition and Affect for Individuals with Depression. Journal of Affective Disorders 140:300-305.

Berto, R 2005. Exposure to Restorative Environments Helps Restore Attentional Capacity. Journal of Environmental Psychology 25:249-259.

Burch, JG 2012. Dementia Garden Design: A Framework to Facilitate Kaplans' Attention Restoration Theory (A.R.T.) in Environments of Care. Master of Landscape Architecture, Kansas State University, Manhattan.

Chang, C-Y, Chen, P-K, Hammitt, WE \& Machnik, L 2007. Psychophysiological Responses and Restorative Values of Wilderness Environments. USDA Forest Service Proceedings RMRS-P-49:479-484.

Clines, DJA 1994. Why is there a Song of Songs and What Does it Do to You When You Read it? Jian Dao 1:3-27. 
De Kort, YAW, Meijnders, AL, Sponselee, AAG \& Ijsselsteijn, WA 2006. What's Wrong with Virtual Trees? Restoring from Stress in a Mediated Evironment. Journal of Environmental Psychology 26:309-320.

De Young, R 2010. Restoring Mental Vitality in an Endangered World: Reflections on the Benefits of Walking. Ecopsychology 2(1):13-22.

Exum, JC 2005. Song of Songs: A Commentary. Old Testament Library. Louisville: Westminster John Knox Press.

Felsten, G 2009. Where to Take a Break on the College Campus: An Attention Restoration Theory Perspective. Journal of Environmental Psychology 29:160-167.

Fontaine, CR 2001. "Go forth into the fields": An Earth-centred Reading of the Song of Songs, pp. 126-142 in Habel, NC \& Wurst, S (eds.), The Earth Story in Wisdom Traditions. The Earth Bible, 3. Sheffield: Sheffield Academic Press.

Fox, M V 1985. The Song of Songs and Ancient Egyptian Love Songs. Madison: University of Wisconsin Press.

Frumkin, H 2001. Beyond Toxicity: Human Health and the Environment. American Journal of Preventative Medicine 20(3):234-240.

Gerleman, G 1981. Ruth. Das Hohelied. 2. Aufl. Biblische Kommentar zum Alten Testament, XVIII. Neukirchen-Vluyn: Neukirchener Verlag.

Habel, N 2011. The Birth, the Curse and the Greening of Earth: An Ecological Reading of Genesis 1-11. The Earth Bible Commentary. Sheffield: Sheffield Phoenix Press.

Hägerhall, C 2014. Biophilia and the Fractal Geometry of Nature. Accessed on 20 March 2015 from www.cemusstudent.se/wp-content/.../C-Hägerhäll-Uppsala-21mars2014.pdf

Hartig, T (s.a.) Toward Understanding the Restorative Environment as a Health Resource. Accessed on 23 March 2015 from www.openspace.eca.ed.ac.uk/conference/proceedings/PDF/Hartig.pdf

Herzog, TR, Maguire, CP \& Nebel, MB 2003. Assessing the Restorative Components of Environments. Journal of Environmental Psychology 23:159-170.

Herzog, TR, Ouellette, P, Rolens, JR \& Koenigs, AM 2010. Houses of Worship as Restorative Environments. Environment and Behavior 42(4):395-419.

Kaplan, R 2001. The Nature of the View from Home: Psychological Benefits. Environment and Behavior 33(4):507-542.

Kaplan, R \& Kaplan, S 1989. The Experience of Nature: A Psychological Perspective. Cambridge: Cambridge University Press.

Kaplan, S 1995. The Restorative Benefits of Nature: Toward an Integrative Framework. Journal of Environmental Psychology 15:169-182.

Kaplan, S 2001. Meditation, Restoration and the Management of Mental Fatigue. Environment and Behavior 33:1-16.

Kaplan, S \& Berman, MG 2010. Directed Attention as a Common Resource for Executive Functioning and Self-regulation. Perspectives on Psychological Science 5(1):43-57.

Kellert, SR 1993. The Biological Basis for Human Values of Nature, pp. 42-69 in Kellert, SR \& Wilson, EO (eds.), The Biophilia Hypothesis. Washington: Island Press.

Keltner, D \& Haidt, J 2003. Approaching Awe, a Moral, Spiritual, and Aesthetic Emotion. Cognition and Emotion 17 (2):297-314. 
LaCoque, A 1998. Romance she Wrote: A Hermeneutical Essay on the Song of Songs. Harrisburg: Trinity Press International.

Landy, F 1983. Paradoxes of Paradise: Identity and Difference in the Song of Songs. Bible Literature 7. Sheffield: Almond Press.

Longman III, T 2001. Song of Songs. New International Commentary on the Old Testament. Grand Rapids: Michigan.

Mayer, FS, Frantz, CMP, Bruehlman-Senecal, E \& Dolliver, K 2009. Why is Nature Beneficial? Environment and Behavior 4(5):607-643.

Melson, GF 2013. Children and Wild Animals, pp. 93-118 in Kahn Jr, PH, Hasbach, P \& Ruckert, J (eds.), The Rediscovery of the Wild. Cambridge, MA: MIT Press.

Meyers C 1988. Discovering Eve: Ancient Israelite Women in Context. New York: Oxford University Press.

Michaelis, J 2011. The Restorative Effects of Color and Environment Type on Cognitive Functioning. Master of Science, University of Central Florida, Orlando.

Munro, JM 1995. Spikenard and Saffron: A Study in the Poetic Language of the Song of Songs. Journal for the Study of the Old Testament Supplement Series 203. Sheffield:Sheffield Academic Press.

Murphy, RE 1990. The Song of Songs: A Commentary on the Book of Canticles or the Song of Songs. Hermeneia. Minneapolis: Augsburg Fortress.

Myers Jr, OE, Saunders, CD, \& Birjulin, AA 2004. Emotional Dimensions of Watching Zoo Animals: An Experience Sampling Study Building on Insights from Psychology. Curator 47(3):299-321.

Pearson, DG \& Craig, T 2014. The Great Outdoors? Exploring the Mental Health Benefits of Natural Environments. Frontiers in Psychology 5.

Internet Front. Psychol. 5:1178.doi.10.3389/fpsyg.2014.01178

Polaski, DC 1997. "What will ye See in the Shulammite? Women, Power and Panopticism in the Song of Songs'. Biblical Interpretation 5:64-81.

Pope, MH 1977. Song of Songs: A new translation with introduction and Commentary. Anchor Bible 7C. New York: Doubleday.

Rudolph, W 1962. Das Buch Ruth. Das Hohe Lied. Die Klagelieder. Kommentar zum Alten Testament, XVII 1-3. Gütersloh: Gütersloher Verlaghaus Gerd Mohn.

Sato, I \& Conner, TS 2013. The Quality of Time in Nature: How Fascination Explains and Enhances the Relationship between Nature Experiences and Daily Affect. Ecopsychology 5(3):197-204.

Thielen, A \& Diller (s.a.) Through the Lens of Attention Restoration Theory: The Pursuit of Learning in Gardens throughout History. Undergraduate Research Journal High School Series (2002-2014) 11:1-10.

Taylor, AF, Kuo, FE \& Sullivan, WC 2001. Coping with ADD: The Surprising Connection to Green Play Settings. Environment and Behavior 33(1):54-77.

Taylor, AF \& Kuo, FE 2009. Children with Attention Deficits Concentrate Better after Walk in Park. Journal for Attention Disorders 12(5):402-409.

Ulrich, RS 1984. View through a Window may Influence Recovery from Surgery. Science 224, 420-422. 
http://scriptura.journals.ac.za

Natural Retreats and Human Well-being: Reading the Song of Songs

Viviers, H 2001. Eco-delight in the Song of Songs, pp. 143-154 in Habel, NC \&

Wurst, S (eds.), The Earth Story in Wisdom Traditions. The Earth Bible, 3. Sheffield: Sheffield Academic Press.

Wilson, EO 1993. Biophilia and the Conservation Ethic, pp. 31-41 in Kellert, SR \& Wilson, EO (eds.), The Biophilia Hypothesis. Washington: Island Press. 